\title{
TAX POTENTIAL OF A STATE: DEVELOPMENT FACTORS
}

\author{
Viktor V. Ivanov \\ St. Petersburg State University, St. Petersburg, Russia \\ Natalia V. Pokrovskaia \\ St. Petersburg State University, St. Petersburg, Russia \\ Nadezhda A. Lvova \\ St. Petersburg State University, St. Petersburg, Russia
}

\begin{abstract}
The article focuses on the nature and factors that define tax potential of a state. Tax potential is unlocked during the process of forming tax liabilities according to an existing procedure and rules of tax assessment. The article also shows relation among the actual, latent and prospective tax base in a current term as well as the level of influence exerted on those by tax evasion and uncollected tax. Value indicators of tax potential assessment are related to tax liquidity. The article justifies that tax potential can be considered as taxes and charges that are able to be paid timely and in full by tax payers according to an existing tax base under the conditions of a tax system that benefits economic development.
\end{abstract}

Keywords: tax potential, tax capacity, tax potential development, regional development

JEL code: $\mathrm{H} 20$

\section{Introduction}

One of the priorities for improving tax systems is to create conditions for increasing tax potential and tax collection as a foundation for budgetary system of a state. The size of tax potential under current conditions is one of the objective indexes of the level of economic development of a region or a state.

The notions of tax potential approaches to its assessment and development have been points of interest since the 1980s (Govinda Rao and Sarma, 1989). Studies conducted by such international organizations as the World Bank and International Monetary Fund focus on empirical analysis of interrelation and influence of tax potential and tax effort (see Kwaja and Iyer, 2014; Langford and Ohlenburg, 2015; Davoodi and Grigorian, 2007; Le et al., 2012). The correlation of factors discovered in case of the developed economies is also relevant to the environment existing in developing ones (Piancastelli, 2001; Gupta, 2007: Alfirman, 2003). At the same time unique features of financial systems (Darushin et al., 2016) and tax reforms being underway (Pokrovskaia et al., 2016) in the emerging markets determine specific approaches towards tax potential analysis. An important aspect of the study into tax potential is analyzing it at regional level in federal states and countries with complex organization (Coondo, 2003).

The purpose of the study is to reveal the nature of the tax potential including the relevant drivers of its growth.

\section{Methodology and Results}

We start our study from various approaches applied to define the tax potential. Then, according to the research purpose, we analyze key components of the tax base, that predetermine the tax potential. The graphical representation is used by the authors to describe 
the process of formation of tax liabilities and to show the dynamics of tax liabilities within a financial year.

In spite of a developed methodology and the intensity of empirical studies of tax potential, tax effort, tax capacity and tax gap, the notion of tax potential remains intricate. World Bank's research of fiscal federalism in Russia estimates revenue potential of a region as follows: each tax base multiplied by the average region tax rate for each base (Wallich, 1994). Consequently, tax potential has been commonly defined in the Russian literature as a capability of tax base to bring in tax revenue within an administrative unit (not the actual amount of revenue).

This interpretation emphasizes tax collection rate and to a lesser degree takes into account features of a specific tax base and taxation system conditions. It assumes that tax revenue is complete by its nature as of the end of a tax period. However, if we analyze taxation processes, a considerable part of due tax revenue become "stuck" due to uncollected taxes and the scale of tax evasion.

The definition of tax potential based exclusively on "a capability of a tax base to bring in revenue" is not, in our opinion, absolutely correct as this approach makes it difficult to estimate the very capability of a tax base to bring in revenue which in its turn is influenced by certain factors while providing actual tax revenue.

A number of researchers consider tax potential as the maximum amount of tax revenue a country could reasonably raise at a given point in time, conditional on its prevailing characteristics (Langford and Ohlenburg, 2015). However, in our opinion, this approach does not take into account other elements of tax potential. Moreover, the amount of calculated tax is formal to a certain extent since the amount of calculated and additional tax charges does not become tax revenue in full as a result of monitoring measures also because of their subsequent adjustments (such as a revised tax declaration, reversal over tax disputes etc.). Thus, maximum amount of tax revenue charged to a budget of a certain level does not completely reflect the nature of tax potential as this particular index does not take into account the condition and dynamics of taxable base, repayment amounts in case of overpayment and VAT refund etc.

The taxable base is considered as a monetary, physical or other characteristic of a taxable item. A distinctive feature of this category is that monetary evaluation of taxable items is valid within a fiscal period that contains deadlines for paying tax liabilities including items involved in the previous fiscal year. Correspondingly, taxable base can have at least three states:

1. actual (declared, calculated);

2. latent (hidden);

3. prospective (not in use).

Actual tax base represents taxable items that are openly involved in economic activity and are voluntarily declared by economic entities on a permanent or occasional basis.

Latent tax base represents taxable items that are deliberately exempted from taxation.

Prospective tax base represents taxable items of economic activity and natural environment that can be involved into economic activity of a region to bring in tax and non-tax revenues in the short or long term. 
Tax revenues and a part of the uncollected tax derive from the actual tax base and describe the degree of its liquidity, i.e. its ability to transform into budget income at any level.

It is critical to understand the formation process of tax liabilities in order to reveal the nature of tax potential. Initially tax liability is formed on the basis of actually existing taxable items within a specific tax period and can expire within or beyond a fiscal period (a month, quarter, year). Correspondingly, an liability to pay tax may emerge within a fiscal year or go beyond the term. Now there is a question how the emerged tax liabilities relate to tax potential in terms of the time lag and within a timeframe on the whole.

The process of forming tax liabilities directly relates to the procedure and rules of tax assessment. It is represented in the Figure 1.

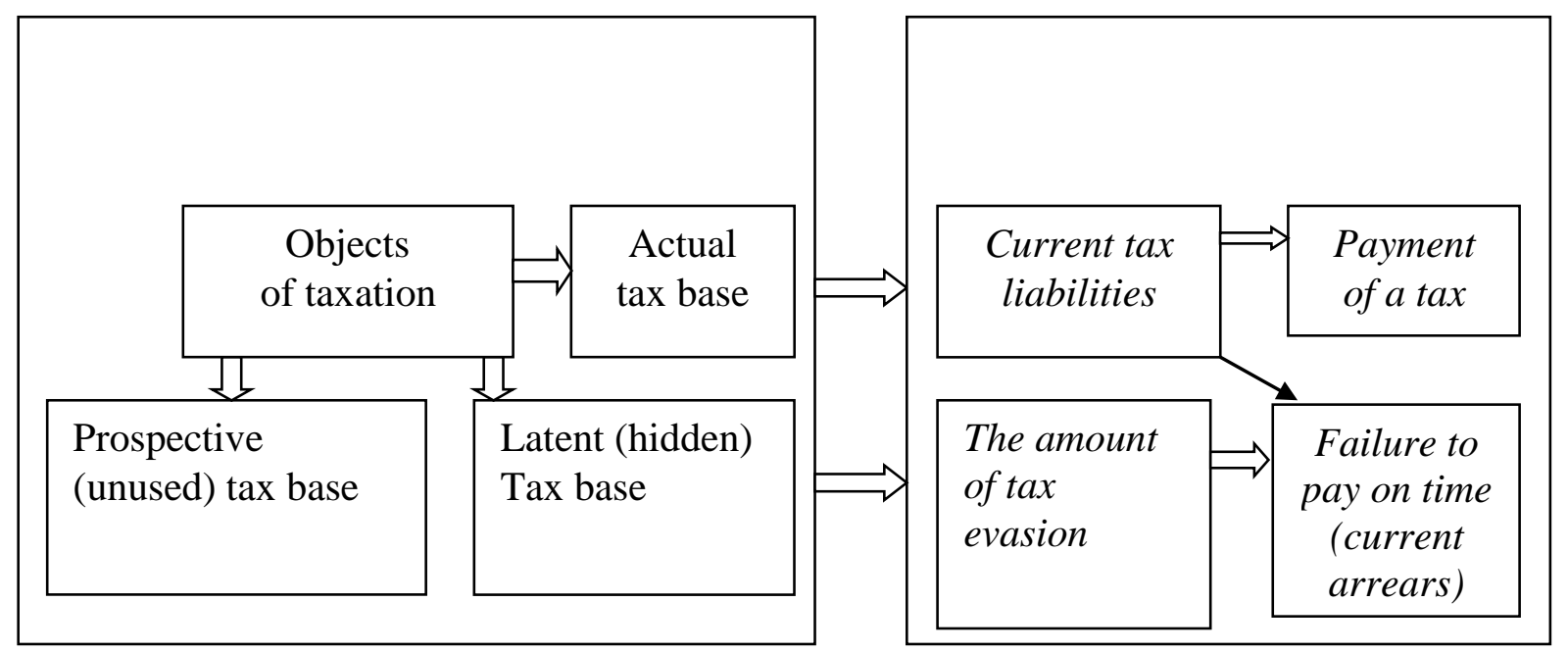

Figure 1. The process of forming tax liabilities

All objects of taxation describe economic conditions outside the taxation sphere. After some of the taxable items fall under taxation they enter a financial and legal category of actual tax base, the volume of which influences the sum of actual tax revenue and uncollected tax (active tax base).

In practice, some part of the tax base has a reverse negative dynamics that can be seen by its shrinkage or the process of exempting taxable items while they actually function as such (passive tax base).

We call a tax base "active" or "passive" depending on its ability to be a source of budget revenue within a given fiscal year. Since tax potential involves multiple elements we believe that tax potential dynamics may have a double nature, namely absolute dynamics, i.e. the change in tax base as a whole and in the sums of uncollected tax, and relative dynamics which is described by changes in the volume of tax potential elements.

Tax base serves as a foundation for converting tax liabilities into actual tax payments, current delinquent taxes and taxes unpaid due to evasion. Figure 1 shows tax base specific features that should include its latent and not-in-use elements. They escape declaration what leads to actual damage for a given budget in terms of tax evasion scale and current delinquent tax. 
Taxable items as a whole serve as a foundation for all the tax liabilities that are involved into economic activities of a region within a given term. Actual tax revenue within a fiscal year exist only with regard to those taxable items and tax base that have the same due dates as the given term (a fiscal year). This means that not all the taxable items are taken into account while estimating annual tax potential.

A current tax liability may be fulfilled within a fiscal year or slide beyond its timeframe sticking to a specific due date. Beside liabilities with sliding due date, the source of budget income also includes the volume of uncollected tax, formation period of which may vary.

If we move this pattern a fiscal year ahead, we will get another element of tax potential: a sum of incoming tax deficiency over previous periods that have to be take into account as well when estimating tax potential since some part of it may be paid next year (see Figure 2).

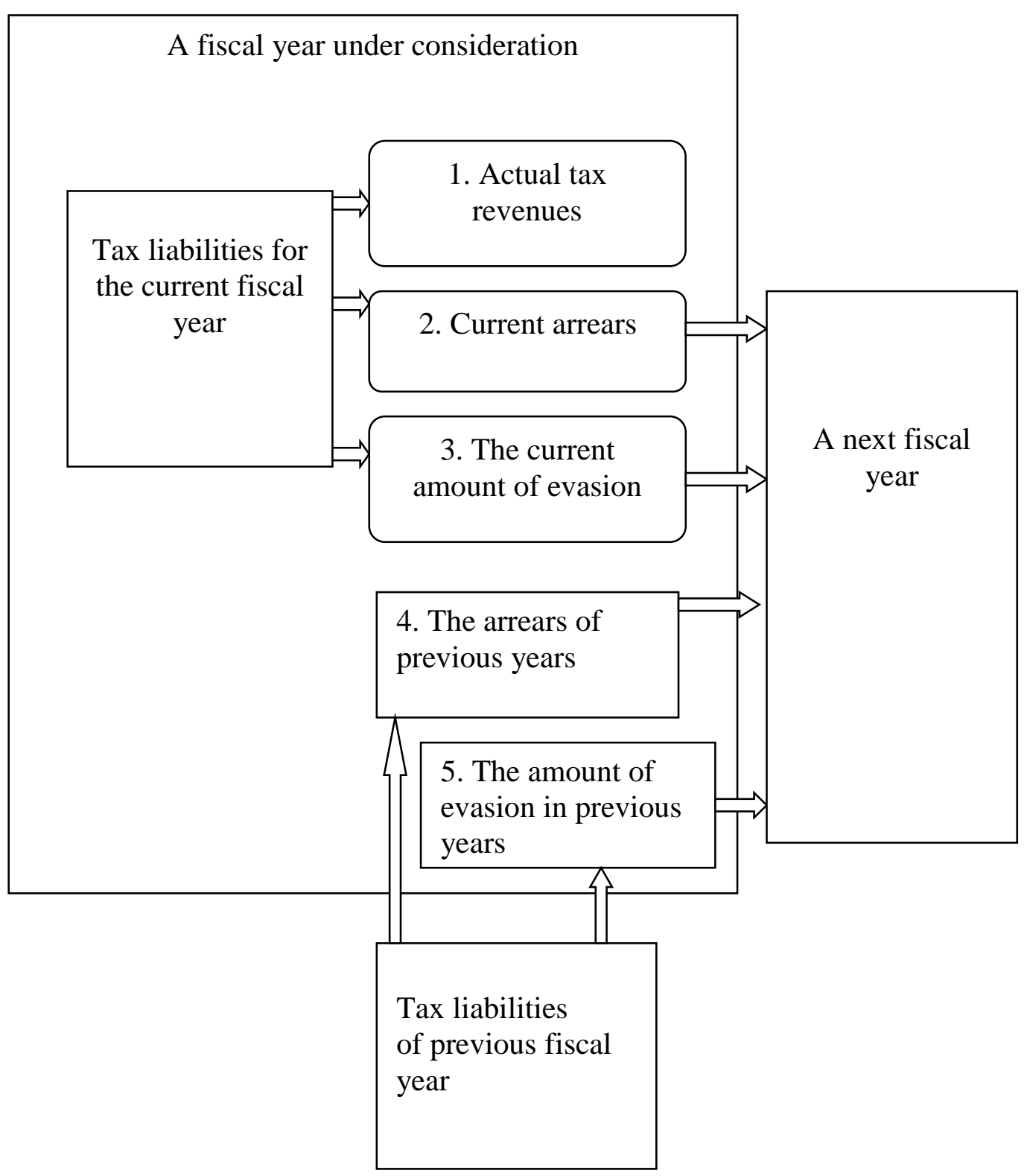

Fig. 2. The dynamics tax liabilities within a financial year 
In our opinion, it is important to take into account four categories of tax liabilities marked in Figure 2 when estimating tax potential. These are current tax delinquency, current tax evasion scale, tax delinquency in the previous years and tax evasion scale in the previous years. They are directly related to tax potential because of their ability to convert mentioned liabilities into actual tax revenue within a given fiscal year.

Because of low tax management efficiency and other factors, some of the liabilities become potential budget revenue for the next fiscal years.

Tax potential is a generalizing category founded on taxable items (including those exempt of taxation), i.e. actual tax base, and on the results of economic activity over the previous years (in terms of delinquent tax and hidden taxes and charges).

At the same time, items exempt of taxation can be put into the prospective tax base category. It includes items of property which are involved into economic activity but are not declared and not taken into account by monitoring bodies and natural environment items capable of delivering positive economic results.

If we place structural elements of taxable items according to taxation liquidity, derived indexes that describe monetary value of tax potential will appear in the following order:

1) the sum of actually paid taxes and charges set against existing overpayment over a taxable period;

2) current tax delinquency over an investigated period;

3) tax evasion scale;

4) tax delinquency in the previous years including cases declared by court as overdue;

5) prospective tax base capable of bringing in tax and non-tax revenues in the short or long term under legislative initiative of government bodies and local authorities and investment activity of tax payers.

Derived indexes of the passive element of tax base include amounts of taxes evaded that determine the scale of tax evasion. They represent financial characteristic of latent tax base and are an integral reserve of budgetary system.

Potential budget revenues obtained from exploiting items belonging to the prospective tax base are another important reserve of tax potential. The base can be divided into two elements:

Real objects currently exempt of taxation (special categories of land property, forest lands, fauna forms, aquatic biological resources etc.);

Potential taxable items that can appear as a result of growing investment, finance and economic activity in a given region and, correspondingly, because of growing tax potential in terms of VAT, income tax etc.

Tax potential development is based on factors determining its structure on the whole. Primary factors are the emerged size of tax base and its structure that provides a sustainable source of tax revenue, all other conditions being equal.

Tax potential's liquidity increases under the following conditions:

1. actual base grows;

2. latent base shrinks (declaration process is underway);

3. prospective base is prepared and involved into economic activity; 
4. amounts of delinquent tax go down.

Liquidity decrease is caused by reverse processes. It is worth to point out that the corpus of factors affects nominal and actual dynamics of tax potential.

Actual increase in tax potential is defined by actual tax base expansion caused by economic upturn, value adjustments and number growth in real property. At the same time tax revenue growth can depend on both the current tax base itself and tax arrears or damages paid as a result of monitoring measures.

Nominal tax potential's growth includes increase in delinquent tax court-ruled for enforcement, finding damage due to the fact of hiding items of absent debtors (legal entities), as well as prospective tax base growth.

Tax potential decrease also has actual and nominal nature. Nominal nature of tax potential's decrease includes writing off delinquent tax due to bankruptcy, wrong tax assessment, withdrawal of taxable items from economic activity.

Actual tax potential decrease is explained through economic slowdown, withdrawal of real property and natural environment items from economic activity, national legislation liberalization.

Thus, from the economic point of view tax potential can be considered as taxes and charges that are able to be paid timely and in full by tax payers according to an existing tax base under the conditions of a tax system that benefits economic development.

This definition reflects an ideal state of taxation system that is provided by:

- timely and in full paid taxes within a fiscal year and a valid timeframe stipulated by legislation;

- evaluation of all the tax base and minimizing tax evasion;

- progressive legislation standards, i.e. tax rules being beneficial to legitimate business and efficient tax management.

It is supposed that

- methods and tax rates used for tax assessment are justified;

- universal observation of tax rules by economic entities;

- absence of bureaucratic barriers in a given region or state that impede both tax system functioning and legitimate economic activity;

- presence of institutions and tools that allow economic entities legitimately pay tax arrears (tax holiday, interest free credit financed by separate funds accumulated by budgets of different levels).

\section{Conclusion}

From the financial point of view, tax potential of a region comprises tax liabilities of economic entities acting within the region and tax due over the previous financial years that can be converted into actual tax revenue under an existing tax system.

One possible way to increase tax potential is delegating powers of tax management, specifically tax amnesty in terms of delinquent taxes for some of existing taxes to regional and municipal authorities. 
The ability to adjust tax burden for economic entities will ultimately allow to indirectly influence tax potential and its liquidity, provide diverse sources for local and regional budgets and increase interest towards adjusting tax burden.

\section{References}

Alfirman, L. (2003). Estimating Stochastic Frontier Tax Potential: Can Indonesian Local Governments Increase Tax Revenues Under Decentralization? University of Colorado at Boulder Working Paper no. 19.

Coondo, D., Majumder, A., Mukherjee, R., Neogi, C. (2003). Tax performance and taxable capacity: analysis for selected states of India. Journal of Public Finance and Public Choice, vol. 21, pp. 25-46.

Darushin, I., Lvova, N. Ivanov, V., Voronova N. (2016). The Russian Stock Market: Is It Still Efficient? In: Innovation Management and Education Excellence Vision 2020: from Regional Development Sustainability to Global Economic Growth. Proceedings of the 27th IBIMA conference in Milan, pp. 818-828.

Davoodi, H., Grigorian, D. (2007). Tax Potential vs. Tax Effort: A Cross-Country Analysis of Armenia's Stubbornly Low Tax Collection. Washington, Internal Monetary Fund, WP/07/106.

Govinda Rao, M., Sarma, J. (1989). Measuring Tax Potential: Some Clarifications. Economic and Political Weekly. Vol. 24, no. 13 (Apr. 1, 1989), pp. 698-700.

Gupta, A. (2007). Determinants of Tax Revenue Efforts in Developing Countries. Washington, Internal Monetary Fund, WP/07/184.

Khwaja, M. S., Iyer, I. (2014). Revenue Potential, Tax Space, and Tax Gap. A Comparative Analysis. The World Bank, http://dx.doi.org/10.1596/1813-9450-6868.

Langford, B., Ohlenburg, T. (2015). Tax revenue potential and effort - an empirical investigation. International Growth Centre Working Paper.

Le, T., Moreno-Dodson, B., Bayraktar, N. (2012). Tax Capacity and Tax Effort: Extended Cross-Country Analysis from 1994 to 2009. The World Bank, http://dx.doi.org/10.1596/18139450-6252.

Piancastelli, M. (2001). Measuring the Tax Effort of Developed and Developing Countries: Cross Country Panel Data Analysis, 1985/95. IPEA Working Paper no. 818.

Pokrovskaia, N., Sokolov, B., Ivanov, V. (2016). Tax reforms for Sustainable Economic Growth of the National Economy: case of China. In: Innovation Management and Education Excellence Vision 2020: from Regional Development Sustainability to Global Economic Growth. Proceedings of the 27th IBIMA conference in Milan, pp. 429-439.

Wallich, K. (1994). Russia and the Challenge of Fiscal Federalism. The World Bank, http://dx.doi.org/10.1596/0-8213-2683-X. 